\title{
PÓŁWYSEP IBERYJSKI I PÓŁWYSEP APENIŃSKI W TRAKTACIE KOSMOLOGICZNYM JANA ZE STOBNICY (1470-1530)
}

Robert K. Zawadzki ${ }^{1}$

https://doi.org/10.18778/8220-421-6.10

\begin{abstract}
In this chapter the author examines the representation of the Iberian and Apennine Peninsula in the astronomical and geographical treatise Introductio in Ptolemaei cosmographiam cum longitudinibus et latitudinibus regionum et civitatum celebriorum of Jan of Stobnica. These two countries provided fertile ground for the Cracow writer to articulate his ideas about the typology of Spain and Italy, their main cities and history. By examining these geographical descriptions, the author of the chapter shows how Jan of Stobnica constructed an image of the Iberian and Apennine Peninsula in keeping with the goals and context of his own work, while creating a vision of the Iberian Peninsula as a land of battles against Saracens, and a place from which transatlantic voyages had begun in order to discover the New World.
\end{abstract}

Keywords: Renaissance literature, geography, Spain, Italy, Polish culture.

Słowa kluczowe: literatura renesansowa, geografia, Hiszpania, Włochy, kultura polska.

1 Uniwersytet Humanistyczno-Przyrodniczy im. Jana Długosza w Częstochowie, Instytut Filologii Polskiej, ul. Armii Krajowej 36a, 42-200 Częstochowa. 
Jan ze Stobnicy ${ }^{2}$ to jeden z reprezentantów czy badaczy uprawianej w Akademii Krakowskiej kosmologii ${ }^{3}$, posługującej się w zakresie astronomii teorią geocentryczną. Dziedzina ta poszerzała jednak znacznie obszar swych poszukiwań, wychodząc poza wąsko pojęte zagadnienie sfer niebieskich, gwiazd i planet - jej przedstawicieli, jak Wawrzyniec Korwin ${ }^{4}$ i Jan z Głogowa ${ }^{5}$, można już nazwać geografami. Geografowie ówcześni dzielą się na dwie grupy. Grupie z Wawrzyńcem Korwinem i Janem ze Stobnicy na czele, którą można określić mianem naśladowczej, w przeciwieństwie do bardziej oryginalnej twórczości Jana Długosza $^{6}$ i Jana z Głogowa, zarzuca się plagiatowość 7 i zbyt uporczywe kopiowanie tekstów innych autorów ${ }^{8}$ - zwłaszcza starożytnych. Jan ze Stobnicy wyciągnął jednak pewne konsekwencje z mimetycznych zasad tworzenia dysertacji naukowej ${ }^{9}$, wyzbywając się w dużej mierze nałogu przepisywania w rozprawie

2 O Janie ze Stobnicy zob. Tarnowska, 1962-1964: 480-481; Barycz, 1935: 250-252; Michalski, 1913: 12-13; Michalski, 1915: 21-80; Gniadek, 1956; Staszewski, 1966: 145-146; Palacz, 1970: 23-28.

3 O tych naukach zob. Buczek, 1963; Iłowiecki, 1981: 31. O rozwoju nauki polskiej w renesansie zob. Skubała-Tokarska, 1983: 41-55; Wielgus, 2005: 71-72, 104-105; zob. też: Knoll, 2016: 363-402.

4 O Korwinie zob. Rott, 1997; Zawadzki, 2013.

5 O Janie z Głogowa zob.: Szczegóła, 1967; Polski Słownik Biograficzny, 1962-1964: 450-452; Estreicher, 1870: 173-184; Estreicher, 1963: 196-197.

6 O twórczości Jana Długosza zob. Szelińska, 1980.

$7 \mathrm{~W}$ renesansie nie istniało właściwie pojęcie plagiatu. Naśladowców, imitatorów, kompilatorów, plagiatorów nie ganiono, wręcz przeciwnie zalecano imitacje uznanych wzorów. Zob. na ten temat: Ziomek, 1994: 325. Zob. też: Markiewicz, 1996: 371.

8 To jedna z cech literatury dawnej, por. Curtius, 2009: 65: „średniowiecze w nieskończoność cytuje".

9 Ciekawa problematyka poetyki średniowiecznego i renesansowego dzieła naukowego wymaga ciągle osobnego i kompleksowego opracowania. Zob. Sokolski, 2010: 15-33; Krawiec, 2010; Awianowicz, 2008; Malewicz, 1980. 
sygnowanej własnym imieniem ustępów zaczerpniętych od pisarzy staroży tnych (o czym niżej).

Niezależnie od oceny stopnia oryginalności polskich badaczy powłoki ziemskiej, trzeba stwierdzić, że plagiatowość stanowi jedno z najciekawszych zjawisk ówczesnej geografii ${ }^{10}$. Największą zasługą tego trendu jest fakt, że oni pierwsi pokusili się o zastąpienie wypowiedzi dawnych historyków na tematy polskie nową tematyką, w miejsce wiadomości o dziejach i położeniu własnego kraju wstawili informacje o trzech kontynentach. Zamieszczone przez nich obszerne relacje o państwach, ludach i krainach Europy, Afryki i Azji stanowią istotne novum w literaturze tego okresu. Można, oczywiście, pod adresem twórczości plagiatowej, formułować wiele oskarżeń, że była sztuczna, nieoryginalna, przepisana, że nie opierała się na badaniach własnych. Te zarzuty są w pełni uzasadnione, mimo to mimetyczność odegrała dużą rolę w polskiej kulturze, przyczyniając się do przyswojenia jej dzieł wybitnych twórców. Adepci naśladowania łączyli jednak kopiowanie z pewną innowacyjnością, starali się dodawać własne uwagi, cudze słowa przeplatali swoimi oryginalnymi wypowiedziami. Warto w tym miejscu podkreślić, że obcy tekst musiał sprawiać wrażenie utworu samodzielnego, a przede wszystkim musiał być dostosowany do polskiego odbiorcy.

Celem tego rozdziału jest między innymi ustalenie, na czym polega plagiatowość dysertacji astronomicznej Introductio in Ptolemaei cosmographiam cum longitudinibus et latitudinibus regionum et civitatum celebriorum (Wprowadzenie do Kosmografii Ptolemeusza wraz z długościami i szerokościami geograficznymi

10 Zjawisko to obecne było także w literaturze późniejszej. Zob. Chemperek, 2003; Chemperek, 2005. 
sławnych krain i państw) ${ }^{11}$ Jana ze Stobnicy ${ }^{12}$. Najwłaściwsze jest wyjaśnienie samego autora, który doszedł do swojej metody naukowej po zapoznaniu się z wypowiedziami klasyków kosmologii antycznej (a1[2]):

11 Dzieło ukazało się w Krakowie w oficynie wydawniczej Floriana Unglera w1512 roku (PAN Biblioteka Kórnicka Cim. Qu. 2009, Cim. Qu. 2010). Wydanie drugie ujrzało światło dzienne w 1517 roku również w Krakowie w wydawnictwie Hieronima Wietora (PAN Biblioteka Kórnicka Cim. Qu. 2134). W niniejszym szkicu korzystam z obu tych wydań, które w zasadzie niczym istotnym się nie różnią. Różnice dotyczą pojedynczych wyrazów, np. na określenie terminu „kaplica” w edycji z 1512 roku pojawia się określenie: capella, zaś w edycji z 1517 roku bardziej poprawne sacellum. Wydanie z 1517 roku posiada ponadto bardziej wyrazistą czcionkę, ułatwiającą lekturę.

12 Dzieło było dedykowane ordynariuszowi poznańskiemu Janowi Lubrańskiemu, o czym Jan ze Stobnicy mówi we Wstępie: „Reverendissimo in Christo Patri et Domino Joanni Reverendissimo in Christo Patri et Domino Joanni viribus ad suam aliorumve utilitatem sese conficere putaverint, id ad bonos principes scribant. Quod mihi fecisse videntur, non quo aliquam illis disciplinam proponant, sed quo gratitudo beneficiorum ab ipsis acceptorum, vel amor, quo eis afficiuntur, innotescat ac eorum ex auctoritate, ad quos libri scribuntur, quaedam ipsis libris accedat autoritas. Horum exemplum ego secutus nomini tuo omni cum reverentia praescripsi quasdam meas lucubrationes vel potius recreationes”. Przekład: „Wielce Czcigodnemu w Chrystusie Ojcu i Panu, Janowi z Bożej łaski Biskupowi poznańskiemu, Jan ze Stobnicy śle pozdrowienie. Nie jest to rzecz nowa, najbardziej czcigodny Dobrodzieju, lecz bardzo często stosowana przez starożytnych, że ci, którzy trudzili się działalnością literacką, sądząc, iż dzięki pomocy Minerwy mogą sobie i innym pożytek przynieść, dedykowali swoje pisma znakomitym władcom. Wydaje mi się, że tak właśnie czynili, nie po to jednak, by tamtym przedstawić jakąś dziedzinę wiedzy, lecz po to, by wyrazić wdzięczność za otrzymane od nich dobrodziejstwa, albo okazać miłość, jaką do nich żywili, albo też po to, by dostojeństwo tych, którym utwory swoje ofiarowali, przeszło na ich własne dzieła. Podążając za ich przykładem dedykuję twojemu imieniu, powodowany szacunkiem, ten oto plon mojej nocnej pracy, czy może raczej wypoczynku". Wszystkie cytaty z dzieła Jana ze Stobnicy w tłumaczeniu autora rozdziału. 
Et ne soli Ptolemaeo laborasse, curavi etiam notas facere quasdam partes terrae ipsi Ptolemaeo aliisque vetustioribus ignotas, quae Americi Vespucii ${ }^{13}$ aliorumque lustratione ad nostram notitiam pervenere. Adieci etiam antiquis quarundam provinciarum civitatumque nominibus alia nova, quibus nunc appellantur velut illorum interpretationes ${ }^{14}$.

Za podstawę nowoczesnej geografii uznał on więc perspektywę aktualnych realiów (nunc), które różniły się od tych obowiązujących w czasach starożytnych, co ograniczało znaczenie dzieł dawnych i wagę wypowiedzi pisarzy antycznych. Koncepcja geograficzna Jana ze Stobnicy nie opiera się w zasadzie na autorach greckich czy rzymskich, lecz jemu współczesnych. Oznacza to, że obraz świata zaprezentowany przez Ptolemeusza i Strabona zastępuje on opisami uczonych żyjących w swojej własnej epoce. Twórczość starożytna przestała być dla niego ostateczną wyrocznią, alfą i omegą wiedzy o kosmosie, jak u Wawrzyńca Korwina, a stała się jednym ze źródeł, które należało uzupełnić i skorygować. Jan ze Stobnicy - jak już mówiliśmy - bazuje na badaniach naukowych i wiedzy geograficznej pisarzy współczesnych, których teksty obszernie cytuje. Autorzy, z których dzieł korzystał Jan ze Stobnicy, to przede wszystkim jego rówieśnik - Martin Waldseemüller (około 1470-1531), niemiecki geograf, autor Cosmographiae introductio, proponujący

13 Americus Vespucius - chodzi oczywiście o Amerigo Vespucciego (18.03.1454-22.02.1512), włoskiego żeglarza, od którego imienia nazwano nowo odkryty kontynent.

14 Przekład: „Nie tylko jednemu Ptolemeuszowi się poświęcałem, opracowałem także pewne informacje o częściach ziemi nieznanych ani Ptolemeuszowi, ani dawniejszym pisarzom. Dane te dotarły do naszej wiedzy dzięki relacji Ameriga Vespucciego i innych autorów. Uwzględniłem również przy antycznych nazwach pewnych krain i państw nowe ich ekwiwalenty, jakie dzisiaj są używane, starając się jakby zamieszczać komentarz do tych terminów". 
nadanie Nowemu Światu15 nazwy Ameryka, od imienia Ameriga Vespucciego (1454-1512); dalej, sławny włoski humanista Eneasz Sylwiusz Piccolomini (1405-1464), czyli papież Pius II (od 1458 roku), twórca między innymi dwóch znakomitych rozpraw De Europa i De Asia; następnie Paweł Orozjusz (zmarł około 423 roku po Chrystusie), apologeta chrześcijański, autor Historiarum adversum paganos libri VII'16; Izydor z Sewilli (około 560-636), twórca sławnej encyklopedii Etymologiarum libri XX seu Origines; i wreszcie Anzelm Polak, przyjaciel Jana ze Stobnicy, mnich reguły Świętego Bernarda ze Sieny, członek Zakonu Braci Mniejszych zwanych wówczas obserwantami, piszący w języku łacińskim swego rodzaju przewodnik po Ziemi Świętej - Terrae Sanctae descriptio ${ }^{17}$.

15 Warto zaznaczyć, że pierwszym w Polsce uczonym, który użył terminu „Nowy Świat” w nawiązaniu do nowo odkrytych lądów był nauczyciel Jana ze Stobnicy - Jan z Głogowa. Pisarz ten uczynił to w krótkiej, lecz wyrazistej wzmiance o żeglarzach portugalskich (Introductorium compendiosum) [76]: „[...] hi, qui anno Domini 1501, similiter anno Domini 1504 missi sunt per regem Portugaliae ad inquirendas insulas mundi et maxime originem piperis et aliarum specierum aromaticarum nobilium navigabant sub aequinoctiali et conspexerunt utrumque polum et stellas forum et invenerunt originem piperis in loco, quem dicunt novum mundum, qui locus antea semper incognitus fuit”. Przekład: „[...] których w roku Pańskim 1501, a także w roku Pańskim 1504, wysłał król Portugalii na okrętach, by zbadali wyspy świata. A ci popłynęli przede wszystkim w okolice równika, do miejsca, gdzie rośnie pieprz i inne gatunki szlachetnych roślin aromatycznych, oglądali oba bieguny i gwiazdy nad nimi, odkryli pieprz w miejscu, które nazwali Nowym Światem, a było to miejsce wcześniej zupełnie nieznane”. Na pionierskość Jana z Głogowa zwrócił uwagę Tazbir, 1973: 14. Badacz ten uważa, że Jan z Głogowa „miał na myśli wyspy odkryte zarówno na zachodniej, jak i wschodniej półkuli (między innymi Cejlon)", podobnie Gansiniec, 1997: 24.

16 O Pawle Orozjuszu zob. Cytowska, Szelest, 1994: 147-159.

17 O Anzelmie Polaku zob: Buczek, 1935: 145. Zob. też: Kaczmarek, 1984: 27. Przegląd poglądów badaczy na twórczość Anzelma dał Rott, 1995: 130-132, zob. też: Zawadzki, 2018: 23-38. 
Układ i tematyka cytowanych tekstów nadaje dysertacji Jana ze Stobnicy niezwykłą wszechstronność 18 . Obecność pięciu autorów w dziele warunkuje nie tylko problematykę utworu, lecz i jego zakres. Jan ze Stobnicy zbudował rozprawę w taki sposób, że przedstawił strukturę całego wszechświata, począwszy od trajektorii planet, a skończywszy na topografii Ziemi Świętej. Korzystał zatem $\mathrm{z}$ Waldseemüllera, dając folgę swoim upodobaniom do rozmaitych kwestii kosmicznych, wprawdzie interpretowanych z punktu widzenia - jak wcześniej stwierdziliśmy - teorii geocentrycznej, ale niezwykle popularnych w epoce przedkopernikańskiej. W charakterystyce obszarów tak europejskich, jak

18 Podkreślał to już Paweł z Krosna, którego elegia, zamieszczona zaraz na początku wstępu dzieła, pełniła rolę reklamy:

Qui freta, qui fontes, populos ac moenia, colles

Quique cupis vasti noscere regna soli,

Huc praecor, huc vultum paulisper verte benignum,

Exiguumque legas, candide lector, opus,

Omnia quo magni clauduntur climata mundi,

5

Quodque fovet variis terra rotunda locis,

Quo populos, urbes mirabere flumina, montes,

Et quae sunt oculis non bene visa tuis,

Quo Ptolemaei subito, mihi crede, videbis,

Et releges sparsim grandia scripta libri, 10

Et quod mille alii docti scripsere libellis,

Hoc parvo invenies conspiciesque libro.

Przekład: „Ty, który pragniesz poznać cieśniny, źródła, narody, warownie, wzgórza, a także królestwa ogromnej ziemi, tutaj, proszę, tutaj zwróć choćby przez chwilę, przyjemną twarz, i czytaj, miły czytelniku, to niewielkie dzieło. Dowiesz się z niego wszystkiego; będziesz wiedział, gdzie (5) kończy się nieboskłon wielkiego świata, dlaczego okrągła Ziemia w różnych miejscach utrzymuje ciepło; zachwycisz się narodami, miastami, rzekami, górami. Nawet to, czego nie widziały nigdy twoje oczy, ujrzysz natychmiast dzięki temu dziełu Ptolemeusza - wierz mi. Będziesz sięgał (10) po ten wielki utwór i księgę tu i tam. A to, co inni uczeni mężowie napisali w tysiącach utworów, znajdziesz i zobaczysz w tej oto małej książeczce”. 
i azjatyckich czerpał z Eneasza Sylwiusza Piccolominiego, teksty Pawła Orozjusza i Izydora z Sewilli wyzyskiwał w wykładzie o Afryce Północnej i Syrii. Brat Anzelm natomiast stał się dla niego źródłem dla przedstawienia ojczyzny Chrystusa. Był więc Jan ze Stobnicy kompilatorem, podobnie jak Wawrzyniec Korwin. Różnili się jednak w sposobie traktowania materiału naukowego. Jak już bowiem zaznaczyliśmy, geografia u Jana ze Stobnicy to nie antyk i anachronizmy, lecz współczesność i aktualność, których wizje prezentował w oparciu o najnowsze publikacje.

Eneasz Sylwiusz Piccolomini ${ }^{19}$, wybitny pisarz i naukowiec, był niewątpliwie największym nazwiskiem w gronie autorów źródłowych Jana ze Stobnicy. Sławę przyniosły przyszłemu papieżowi między innymi utwory o tematyce geograficzno-chorograficznej, do których dochodził poprzez mozolną pracę nad tekstami mniej lub bardziej dawnymi oraz różnymi informacjami pozyskanymi w bibliotekach i podczas licznych podróży dyplomatycznych. Do utworów tych należy przede wszystkim syntetyczne dzieło De Europa (1458), studium o kontynencie, ciekawe jeszcze z tego punktu widzenia, że poszczególnym kwestiom geograficznym towarzyszą partie o charakterze wybitnie historycznym. Uwagi o położeniu poszczególnych państw, ich przestrzennym zróżnicowaniu przyrodniczym i społecznym, łączą się w nim $\mathrm{z}$ wypowiedziami o wypadkach dziejowych, o sławnych zdarzeniach i postaciach, co sprawia wrażenie, jak gdyby autor chciał stworzyć kompleksową, całościową wizję danej krainy, co jednocześnie było ważne dla czytelnika, który otrzymywał w jednym tekście wszystkie najważniejsze o niej informacje. Jan ze Stobnicy z aprobatą odnosił się do ujęcia chorograficzno-historycznego Piccolominiego, który w tego rodzaju dwojaki sposób opisał wszystkie ówczesne państwa europejskie, skłaniając krakowskiego uczonego, by uznał taką metodę za najwłaściwszą. Niestety, o czym wspomniano już w tym artykule, pragnąc ją zastosować w swoim dziele, postąpił w sposób najłatwiejszy, czyli

19 O życiu i twórczości Piccolominiego zob. Ojrzyński, 2014, tam też bogata bibliografia. Zob. też: Bisaha, 2013: 3-45. 
przepisał po prostu obszerne fragmenty z dzieła Piccolominiego, gdzieniegdzie jedynie zamieścił własne uwagi i komentarze.

Dysertacja włoskiego humanisty zawierała oczywiście wykład o Półwyspie Iberyjskim i Półwyspie Apenińskim, stanowiący swego rodzaju zamknięty referat o leżących w tej części Europy krainach, państwach i księstwach, nasycony informacjami o aktualnych wydarzeniach i władcach panujących na tych terenach. Piccolomini rozpoczął swą wypowiedź od wykładu na temat Półwyspu Iberyjskiego, która to forma stanowiła typowy przejaw jego naukowej postawy. Wywód operuje piętnastowieczną tematyką, aktualną i właściwą czasom autora. Sposób wykorzystania tego ustępu przez Jana ze Stobnicy jest nader charakterystyczny. Passus musiał napisać Piccolomini przed rokiem 1458, kiedy Andaluzja z miastem Grenadą (Granada) na czele znajdowały się ciągle jeszcze w rękach Arabów. Był to więc tekst w zasadzie trochę już zdezaktualizowany na początku XVI wieku, kiedy Jan ze Stobnicy wydawał swoją Introductio i kiedy wspomniane wyżej miasto nie należało już do muzułmanów, którzy - jak wiadomo - w 1492 roku zostali ostatecznie pokonani i wyparci z Hiszpanii przez wojska Kastylii.

Wykład Jana ze Stobnicy o Półwyspie Iberyjskim łączy wypowiedź Piccolominiego z własną interpretacją, z próbą uaktualnienia informacji podanych przez włoskiego pisarza. Widać, że u krakowskiego uczonego władanie cudzymi słowami jest przemyślane i w niczym nie krępuje jego osobistych konstatacji. Wersja Polaka odznacza się krytycyzmem wobec ustaleń twórcy z Italii, które przecież musiały zostać poddane rewizji w świetle najnowszych wydarzeń. Autor Introductio nie unika, oczywiście, cytatów zaczerpniętych z dzieła De Europa, co nie przeszkadza temu, że jego ujęcie zyskuje znamiona oryginalności. W Introductio mamy zatem dwa teksty: fragmenty rozprawy Piccolominiego i opracowanie Jana ze Stobnicy, z tym, że między jedną a drugą wypowiedzią nie ma dysonansu, obie łączą się ze sobą harmonijnie.

Pierwsze uwagi o Hiszpanii rozpoczynają się cytatami z dysertacji Piccolominiego - pochodzą one z części wstępnej wykładu, w której włoski pisarz zamieścił ogólną charakterystykę kraju [52]: 
Hispania latissima regio et terra optimis comparanda 20 viris armisque potens, hoc anno nostro in plura regna divisa est. Primum ac maximum Castellae regnum appellant, proximum Aragonum, tertio loco - Portugalense ${ }^{21}$.

Ta część wstępna wykładu Piccolominiego pojawia się zatem w wersji Jana ze Stobnicy i rozpoczyna jego dyskurs o Półwyspie Iberyjskim. Następne motywy i opisy kraju nad rzeką Ebro, stanowiące już własne uwagi krakowskiego pisarza, są z tego początkowego passusu wyprowadzone, wiąże się z nim również jednolitość i harmonia tego fragmentu polskiej dysertacji. Początkowy fragment jest bowiem tak napisany, że zawiera się w nim typologia Hiszpanii, jej podział, szeregowanie na poszczególne królestwa. Zarysowuje się tu jednocześnie quasi projekt całej wypowiedzi, z którym czytelnik zapoznaje się od razu w pierwszych zdaniach, zdradzających zasadnicze tematy wykładu i stanowiących główne punkty jego planu czy programu.

Część druga ustępu, opisująca Portugalię, przynosi zatem zmianę tekstu na własny, oryginalny, autorstwa samego Jana ze Stobnicy. Idea korygowania Piccolominiego opanowuje tutaj polskiego pisarza i nie pozwala mu przytoczyć wywodu Włocha o Kastylii i jej władcach. Krakowski uczony uznał zapewne, że uwagi hierarchy o gockim pochodzeniu królów tej krainy, o poczynaniach Alvaro de Luna, czy Juana z Nawarry, nie muszą w jakiś sposób zasługiwać na uwagę czytelnika Introductio, owa relacja bowiem była zbyt odległa od oczekiwań polskiego odbiorcy. $Z$ zapałem natomiast postanowił rozpowszechniać informację o wyprawach zamorskich, jakie dokonywały się z Półwyspu Iberyjskiego, o odkryciach geograficznych, o nieznanych

$20 \mathrm{~W}$ edycji z 1512 roku błędna forma: comperanda. W edycji z 1517 roku poprawnie: comparanda.

21 Przekład: „Hiszpania, kraj bardzo rozległy, który można porównywać z najpotężniejszymi krajami świata, zasobny w ludzi i armie, podzielił się w naszych czasach na szereg królestw. Królestwo Kastylii uchodzi za pierwsze i największe, drugie miejsce zajmuje Królestwo Aragonii, a trzecie - Królestwo Portugalii”. 
lądach, do których docierali żeglarze wypływający na okrętach z tej krainy. Pisząc swój traktat, Jan ze Stobnicy studiował - jak już mówiliśmy - rozprawę Cosmographiae introductio Martina Waldseemüllera, entuzjazmując się zwłaszcza owym passusem, w którym niemiecki uczony wspominał o odkryciu Nowego Świata ${ }^{22}$. W tych opisach nie tylko nie było wiadomości nieważnych, lecz stanowiły one tak wielką sensację, że w wykładzie o Półwyspie Iberyjskim Jan ze Stobnicy nie mógł powstrzymać się, aby sam od siebie nie głosić o faktach, jakie zapoczątkowane zostały w jednym $\mathrm{z}$ tamtejszych królestw:

Portugalense, [...] cuius sceptra nostra aetate moderatur gloriosus princeps Emanuel huius classes victriciaque signa non sine omnium magna admiratione nunc ad antipodas, nunc ad austrum, hiemale, solstitium transcendentes, nunc ad ortus solis usque ad Taprobanam insulam et mille alia loca nobis incognita penetrarunt ${ }^{23}$.

W cytowanym passusie Jan ze Stobnicy wspomina króla Manuela I Szczęśliwego (1469-1521) z dynastii Aviz, z upodobaniem i pasją pisze o jego wielkości oraz oczywiście o wyprawach dalekomorskich. Choć w gruncie rzeczy ogranicza się do ogólników, to jednak jego uwagi o ekspedycjach na antypody, na północ

22 Jan ze Stobnicy mówi o tym fakcie następująco: „Similiter in occasu ultra Africam et Europam magna pars terrae, quam ab Americo eius repertore Americam vocant, vulgo autem Novus Mundus dicitur”. Przekład: „Podobnie na zachodzie świata, poza Afryką i Europą odkryto wielką połać Ziemi, którą nazwano Ameryką od Ameriga Vespucciego - jej odkrywcy, obdarzoną też powszechnie mianem Nowego Świata".

23 Przekład: „Królestwo Portugalii, [...] w której władzę w naszych czasach dzierży wspaniały król Emanuel. Jego okręty i zwycięskie znaki, którym towarzyszy wielki podziw wszystkich, docierają teraz na antypody, zmierzają teraz na południe, północ, tam, gdzie dzień trwa tyle samo czasu, co noc, kierują się tam, gdzie słońce wschodzi - ku wyspie Taprobane i ku tysiącom innych miejsc, nieznanych nam". 
i południe stanowią w literaturze polskiej istotne novum, należą już do epoki nowej, naznaczonej właśnie odkryciami nieznanych krain. Chciałoby się powiedzieć, że w konstatacjach polskiego pisarza unosi się duch humanizmu, podziwu i uznania dla ludzkich dokonań, powiew renesansowej fascynacji zewnętrznym światem.

Wspomniane już było, że Jan ze Stobnicy starał się przeplatać swoją wypowiedź cytatami z Piccolominiego, które były specjalnie dobrane, odpowiednie do danego tematu, jakby chciał poprzedzać własny wywód wprowadzeniem. Tak i tutaj, po zakończeniu wykładu o Portugalii, autor Introductio przeszedł natychmiast do omówienia następnych iberyjskich krain. Rozpoczął oczywiście przytoczeniem z tekstu Piccolominiego, krótką uwagą, nawiązującą do zaprezentowanej wcześniej typologii Hiszpanii: "Quarto Navarrae, Granatae, quod ab Evangelio Christi alienum est ultimum ponunt"24. W ukazanym przez Jana ze Stobnicy pejzażu Hiszpanii uderzał z pewnością polskiego czytelnika podział tej krainy na poszczególne królestwa o dźwięcznych nazwach. W uszach mieszkańców Rzeczypospolitej ładnie brzmiały nasycone samogłoskami i spółgłoską „r” wyrazy, takie jak Navarra czy Granada, choć, rzecz jasna, epatowanie tymi słowami nie jest $\mathrm{w}$ cytowanym ustępie najważniejsze. Istotne są informacje, jakie polski czytelnik czerpał z passusu, zwłaszcza te, które dotyczyły andaluzyjskiego miasta. Szczególne znaczenie posiada tu wzmianka, że nie wyznawało ono Ewangelii Chrystusa. Wiadomość ta pochodząca - przypomnijmy - od Piccolominiego, odnosząca się do czasów, kiedy południowe tereny Hiszpanii znajdowały się pod panowaniem muzułmanów, była anachroniczna, choć niewątpliwie szokująca i budząca zaciekawienie. Krakowskiego badacza, który zamierzał przedstawić aktualny obraz świata, uderzyć musiała przestarzałość takich informacji. Na początku XVI wieku Grenada - jak wiadomo -nie była to już kraina pogaństwa, obcej kultury $\mathrm{z}$ lat dziewięćdziesiątych XV wieku,

24 Przekład: „Czwarte miejsce wśród królestw hiszpańskich zajmuje Królestwo Nawarry, ostatnie zaś Królestwo Grenady, które nie wyznaje Ewangelii Chrystusa”. 
nie była to również kraina dynastii Nasrydów. Południowa Hiszpania w czasach Jana ze Stobnicy była terenem chrześcijańskim, odbitym z rąk Saracenów. Wszystko to polski pisarz postanowił czytelnikom przypomnieć:

Quod urbem habet eiusdem nominis maximam munitissimam, bellicosissimam, opulentissimam, quam numquam antea a Christianis debellatam, nostro aevo rex Hispaniae Ferdinandus Saracenis, qui in occidente grassabantur, decennali obsidione et bello abstulit, Christianitatique adiecit, anno a navitate Domini $1492^{25}$.

W sprawach związanych z sytuacją Grenady Jan ze Stobnicy poczynił zadziwiająco dużo trafnych obserwacji, a jego uwagi w świetle dzisiejszej wiedzy należy uznać za rzeczowe i obiektywne. Jedno nie ulega wątpliwości: król Ferdynand II Katolicki (1452-1516) zdobył stopniowo emirat Grenady w dziesięcioletnich zmaganiach wojennych (1482-1492) i na odzyskanych terenach zaprowadził chrześcijaństwo. Przekazał tutaj Jan ze Stobnicy informacje pewne, wiarygodne, poświadczone w innych źródłach, potrafił uzupełnić konstatacje Piccolominiego, poszerzyć je o najnowsze dane. Podobna rzetelność cechuje zresztą cały przytoczony ustęp: Grenada rzeczywiście była kwitnącym regionem gospodarczym, stanowiła bezspornie centrum kultury i sztuki. Wypowiedź krakowskiego pisarza nabrała zdecydowanego, historycznego znaczenia. Wypada tylko zaznaczyć, że osiągnięcia Jana ze Stobnicy nie dają się zestawić z żadnymi innymi źródłami literackimi, które byłyby obecne w Polsce. Mówiąc innymi słowy: ciekawą rzeczą byłoby ustalić, skąd Jan ze Stobnicy

25 Przekład: „W królestwie tym znajduje się miasto posiadające nazwę taką samą, jak całe królestwo. Jest to największe miasto w tym kraju, świetnie ufortyfikowane, najwaleczniejsze i najbogatsze, którego wcześniej chrześcijanie nie potrafili zdobyć. Jednakże w naszych czasach Ferdynand - król Hiszpanii po dziesięcioletnim oblężeniu zdobył miasto, a Saracenów, którzy grasowali na zachodzie kraju, pokonał na wojnie i tereny te przyłączył do chrześcijaństwa w roku 1492 od narodzenia Chrystusa”. 
czerpał informacje o królu Ferdynandzie, walkach z Saracenami i odzyskaniu Grenady, skoro Piccolomini z oczywistych względów nic o tych faktach nie mógł wiedzieć. Wydaje się, że można tłumaczyć te kwestie ówczesnymi wydarzeniami, na przykład migracjami ludności, czy założeniem, że do Polski przybywali uchodźcy z Hiszpanii, zwłaszcza nienawróceni na katolicyzm Żydzi ${ }^{26}$, wygnani po 1492 roku przez króla Ferdynanda. W takim wypadku przybysze ci osiedliwszy się w Polsce, mogliby po prostu opowiedzieć mieszkańcom naszego kraju o doświadczeniach, jakie wynieśli z dawnej ojczyzny. Myślę, że Jan ze Stobnicy, który jako pracownik Uniwersytetu Krakowskiego był przecież osobą publiczną, stykał się z tymi ludźmi. To właśnie od nich czerpał wiedzę o najważniejszych wydarzeniach dokonujących się wtedy w Hiszpanii.

A zatem Jan ze Stobnicy to po trosze historyk, czego dowodem jest passus poświęcony Grenadzie. Znamiona jego historycznych zapatrywań widać też w rozważaniach na temat miasta Santiago de Compostela - metropolii położonej w północno-zachodniej Hiszpanii, na zachodnim pogórzu Gór Kantabryjskich, około 30 kilometrów od wybrzeża Oceanu Atlantyckiego. To miejsce powstało i rozwinęło się wokół sanktuarium sławnego z postaci jednego z Apostołów, „brata Pańskiego”, krewnego Chrystusa - Jakuba. Podobno ów Jakub, zwany Starszym, który prowadził działalność misyjną wśród iberyjskich Celtów, a później został skazany na śmierć przez władze kapłańskie w Jerozolimie w 44 roku po Chrystusie, spoczął właśnie tutaj. Jan ze Stobnicy doskonale o tym wiedział i o tym napisał:

Est etiam regnum Galliciae, quod longe lateque vulgatur propter communem peregrinationem ad divum Jacobum Apostolum, qui in civitate Novio nunc Compostella quiescit ${ }^{27}$.

26 Zob. Niklewiczówna, 1998: 310. Zob. też: del Rio, 1970: 155-156.

27 Przekład: „Jest jeszcze w Hiszpanii Królestwo Galicji. Jego sława rozprzestrzenia się wzdłuż i wszerz, a słynie ta kraina z pielgrzymek do grobu Świętego Jakuba apostoła, który spoczywa w mieście Novium - obecnie Compostela”. 
Sława sanktuarium Świętego Jakuba utrwaliła się w świadomości ówczesnego pokolenia. Wywód Jana ze Stobnicy stanowi tego przykład. Także z innych zabytków piśmiennych, jakie dotrwały do naszych czasów, wiemy, że ta sława była spowodowana pielgrzymkami, zrodziła się ze względu na licznych pątników, wyruszających do grobu Apostoła, także z Polski. Relacje tych ludzi mogły Janowi ze Stobnicy wystarczyć, by stworzyć cytowany wyżej passus. Niemniej zastanawia nas też fakt, że Jan ze Stobnicy znał termin Novium, stanowiący rzymską nazwę hiszpańskiego miasta i że pojęcie to raczej chyba nie było wówczas używane przez polskich pielgrzymów. Pewności jednak, czy wyraz Novium oni znali, czy też Jan ze Stobnicy wiedzę o świętym miejscu Hiszpanii czerpał z innych źródeł, mieć nie będziemy bez wszechstronnych badań, w tym zwłaszcza tekstów piętnastowiecznych, znajdujących się w Bibliotece Jagiellońskiej.

Wypowiedź Jana ze Stobnicy o Hiszpanii jest w literaturze staropolskiej swego rodzaju unikatem. Nigdy wcześniej w Polsce nie przedstawiono kraju nad rzeką Ebro tak jednolicie, przy czym warto jednocześnie podkreślić, że opis tej krainy stapia się u Jana ze Stobnicy silnie z próbą przedstawienia jak najświeższych danych, a geograficzny wykład naukowy z nieugiętym wysiłkiem badacza, by uwzględnić najnowsze i najlepsze opracowania naukowe.

Wywodem o Półwyspie Iberyjskim poprzedził polski uczony opowieść o Półwyspie Apenińskim. Jan ze Stobnicy miał tu znowu do dyspozycji dzieło De Europa Piccolominiego. Relacja o Italii jest u włoskiego pisarza najobszerniejsza, stanowi trzecią część jego utworu. Piccolomini przedstawił w nim swój własny kraj, pełen niezwykłości, a zarazem zwyczajnych zdarzeń społecznych i gospodarczych, naznaczonych wielkimi postaciami, a przy tym uwikłany w sieć intryg politycznych, snutych przez różne europejskie mocarstwa ${ }^{28}$. Kraj ten opisany został - powtórzmy - przez autochtona, erudytę i naukowca, a zatem przez człowieka najbardziej kompetentnego. Cóż zatem łatwiejszego, wydawałoby

28 Relacja Piccolominiego zyskała obszerne omówienia w licznych opracowaniach. Zob. np. Martines, 1988; Baldi, 2003: 619-683. 
się, jak tekst po prostu przepisać - kopiowanie stało się przecież cechą metody pisarskiej Jana ze Stobnicy. A jednak krakowski uczony postąpił inaczej, zrezygnował z dysertacji Piccolominiego. Zadecydowały po prostu te same, co w opowieści o Hiszpanii, czynniki: długość i treść włoskiego wywodu. Wykład autora De Europa był zbyt obszerny, omawiana problematyka mało interesująca, zbyt odległa dla polskiego czytelnika. Jan ze Stobnicy był pisarzem liczącym się z możliwościami odbioru jego dzieła. Element erudycyjny został w pracy krakowskiego profesora ograniczony do najkonieczniejszego minimum wiedzy o Italii. Jego ambicją było jedynie ujęcie najistotniejszych kwestii, oświetlenie ich na najważniejszych płaszczyznach, uwzględniających przede wszystkim topografię i odległości wyznaczające wielkość tego kraju. Rzecz znamienna, że tym razem Jan ze Stobnicy spojrzał na te zagadnienia oczami starożytnych autorów, podjął wysiłek znalezienia odpowiednich danych u Pliniusza, a zwłaszcza u Solinusa. Uznał zapewne, że wypowiedzi te będą bardziej przydatne niż książka Piccolominiego, traktują bowiem o sprawach, które w geografii są w gruncie rzeczy niezmienne. Pisząc o Półwyspie Apenińskim, wybrał więc odpowiednie ustępy z dzieł tych dwóch Rzymian jako najwłaściwiej pod względem geograficznym oświetlające problematykę chorograficzną Italii:

Italia omnis inter Adriaticum et Tuscum mare, sive Superum et Inferum in forma cruris vel brachii extenditur. Et a iugis Alpium, quibus ad septentrionem a Gallia et Germania clauditur, porrecta Appennino monte, quo tota secundum longitudinem dividitur, veluti dorso sese attollens usque ad Rheginum verticem et litora Brutiorum ${ }^{29}$, ex quibus brevissimus transitus in Siciliam est, protenditur. Nam in ultimo sui in duo cornua scinditur, quorum alterum et quod brevius est Ionium respectat aequor, alterum Siculum ${ }^{30}$, in extremitate Rhegium oppidum continens. Cuius longitudo

29 Cf. Solinus, De mirabilibus mundi 2, 19.

30 Ibidem 2, 21. 
ab Augusta Praetoria ${ }^{31}$, quae, ut dixit Plinius libro quarto, in Alpineo fine sita ${ }^{32}$, per Romam Capuamque porrigitur usque ad oppidum Rhegium, teste Solino, decies centena et XX milia passuum colligitur, latitudo vero ubi plurimum quadrigenta decem, ubi minimum centum triginta sex milia, [...] umbilicum, ut Varro tradit, in agro Reatino habet ${ }^{33}$.

Odnajdując w przytoczonym passusie cytaty z Solinusa i Pliniusza warto zwrócić uwagę, że zostały one bardzo umiejętnie dobrane i wkomponowane w całość wypowiedzi. Stanowi to, jak wiadomo, swoisty znak rozpoznawczy sztuki pisarskiej Jana ze Stobnicy. Topografia Italii przedstawiona jako zwarty i zwięzły wykład - to była proza odpowiadająca oczekiwaniom ówczesnych czytelników.

Gdy śledzimy uczone wywody Jana ze Stobnicy, szybko możemy powziąć przeświadczenie, że żądał od dysertacji naukowej

31 Augusta Praetoria miasto w tak zwanej Gallia Transpadana, dziś: Aosta.

32 O tym pisze Pliniusz nie w czwartej, lecz w trzeciej księdze swego dzieła. Zob.: Plinius, Historia Naturalis 3, 123: „Augusta Praetoria iuxta geminas Alpium fores...".

33 Cf. Solinus, op.cit., 2, 23. Przekład: „Cała Italia leży między Morzem Adriatyckim i Tyrreńskim, czyli Morzem Górnym i Dolnym. Posiada ona kształt goleni czy ramienia. Począwszy od masywu Alp, które na północy oddzielają ją od Galii i Germanii, piętrzy się pasmem górskim Apenin biegnących przez całą jej długość. Jakby unosząc plecy, ciągnie się aż do przylądka Regium i wybrzeży Brutium, skąd jest najkrótsza morska droga na Sycylię. Na samym swoim końcu rozszczepia się na dwa różki, z których jeden jest krótszy i kieruje się w stronę Morza Jońskiego, a drugi, na którego koniuszku znajduje się miasto Regium, zwraca się w stronę Morza Sycylijskiego. Długość Italii mierzona od miasta Aosta, które, jak powiada Pliniusz w czwartej księdze swego dzieła, leży u podnóża Alp, przez Rzym, Kapuę aż do miasta Regium, wynosi, zdaniem Solinusa, milion dwadzieścia tysięcy kroków, szerokość zaś - w miejscu najszerszym - to czterysta tysięcy kroków, w miejscu najwęższym - sto trzydzieści tysięcy, [...] środek Italii, jak chce Warron, znajduje się w mieście Reate [Rieti]”. 
spełnienia jednego podstawowego warunku, mianowicie pozostania jej w przyrodzonych granicach, realizowania zasadniczej domeny, jaką jest funkcja informacyjna. Pokazywał, że względy utylitarne, praktyczne uważał w rozprawie za ważniejsze od czysto literackich i innowacyjnych, mających świadczyć o oryginal ności badacza. Jeśli więc wypowiedź naukowa jest formą, która, choć oparta na najznakomitszych opracowaniach, nie potrafi sprostać pragnieniom odbiorców, tym szybciej należy z niej zrezygnować, w takim bowiem razie naukowiec chcący zaciekawić czytelników musi tę formę porzucić, aby szukać innych, mniej erudycyjnych, bardziej współczesnych i użytecznych, bardziej dla odbioru adekwatnych sposobów wypowiedzi. Tak właśnie zrobił Jan ze Stobnicy w dalszej części wykładu o Italii. Nastąpił tu po prostu odwrót od cytatów z Piccolominiego i innych autorów. Krakowski profesor, uznając zapewne, że nie będą przydatni dla realizacji jego celów, własnymi słowami, zupełnie samodzielnie tak zakończył wywód o Półwyspie Apenińskim:

Haec dudum, teste Plinio in libro tertio, ex latere maris Superi Rubiconem fluvium pro finibus habuit, ita ut a Rubicone usque ad Alpes Gallia fuerit, quae Cisalpina togataque dicebatur et non Italia, ubi est Mediolanum, Ticinum ${ }^{34}$ et Comum ${ }^{35}$, sed nunc et haec pars in nomem Italicum transiit. Partiales autem Italiae regiones sunt: Campania, Calabria, Lucania, Apulia, Sabinia, Thuscia, Umbria, Latium, Etruria, Marchia et in ea Galliae parte, quae ab usu togae togata, ab Italis Cisalpina dicitur, Liguria trans Padum, Insubria et Venetia citra Padum ${ }^{36}$.

34 Ticinum miasto w Galii, dziś: Pavia.

35 Comum miasto w tak zwanej Gallia Cisalpina, dziś: Como.

36 Przekład: „Granicę Italii od strony Morza Adriatyckiego stanowiła od zawsze, zdaniem Pliniusza wypowiadającego się w księdze trzeciej swego dzieła, rzeka Rubikon. A zatem pas ziemi zawarty między Rubikonem a Alpami stanowił Galię, którą określano mianem Cisalpina albo Togata, a nie Italia, choć leżą tu miasta Mediolan, Pavia i Como. Niemniej dzisiaj i ta kraina nazywa się Italią. Cała zaś Italia składa się z następujących krain: 
Wywód cytowany zatem poszedł tu drogą własnych konstatacji pisarza, drogą wygłaszania komentarza autorskiego, komentarza geograficzno-historycznego, który formalnie stanowiąc ogólną charakterystykę Italii, sygnalizował istną rzekę zagadnień nie tylko chorograficznych, lecz także literackich. Autor dla uwypuklenia pewnych sławnych tematów i podkreślenia ich ważności nie wahał się przywołać pojęć i nazw pełniących w piśmiennictwie europejskim niejednok rotnie funkcję symbolu, jak Rubikon czy Galia Cisalpina. Krakowski geograf był zarazem krzewicielem kultury, dał temu wyraz wprowadzając słynne terminy i określenia do swojego kraju - kraju, który dopiero co wstępował na ścieżki humanizmu.

Wypowiedź Jana ze Stobnicy o Półwyspie Iberyjskim i Półwyspie Apenińskim spełniła swoją funkcję. Dziś można tę dysertację traktować jako ważne i trwałe osiągnięcie polskiej geografii epoki renesansu. Uwagi krakowskiego uczonego o typologii i topologii Hiszpanii i Italii, relacje o zwycięstwie nad muzułmanami w Grenadzie, informacje o grobie Świętego Jakuba w Santiago de Compostela, przywoływanie sławnych miejsc $\mathrm{z}$ historii starożytnego Rzymu i nowożytnych Włoch - wszystko to stało się własnością polskiej literatury, istotnym i niepodważalnym ogniwem kultury ówczesnej Rzeczypospolitej. Niepodważalnym, bo Jan ze Stobnicy szedł niejednokrotnie własną drogą, która jednak choć może nie w pełni indywidualna i oryginalna, zaprowadziła go do celu dydaktycznego, a zarazem naukowego, jakim było zapoznanie polskiego czytelnika z dwoma sławnymi, europejskimi krajami. Geograficzne konstatacje Jana ze Stobnicy są osiągnięciem bezspornym, stanowią część polskiej nauki o Ziemi, potwierdzają jednocześnie, że nasi przodkowie interesowali się tymi państwami, czyli pośrednio o związkach łączących Polskę z Hiszpanią i Italią.

Kampania, Kalabria, Lukania, Apulia, Sabinia, Tuscia, Umbria, Latium, Etruria, Marche. A w tej części Galii, którą ze względu na obyczaj noszenia tog określa się mianem togata i którą Włosi nazywają Cisalpina, znajduje się - za rzeką Pad - Liguria, a także Insubria, a z tej strony Padu leży Wenecja”. 


\section{Bibliografia}

Awianowicz, B. (2008): Progymnasmata $w$ teorii i praktyce szkoly humanistycznej od końca XV do połowy XVIII wieku. Toruń: Wydawnictwo Naukowe UMK.

Baldi, B. (2003): Enea Silvio Piccolomini e il De Europa: umanesimo, religione e politica. „Archivio storico italiano” 161: 619-683.

Barycz, H. (1935): Historia Uniwersytetu Jagiellońskiego w epoce humanizmu. Kraków: Wydawnictwo UJ.

Bisaha, N. (2013): Introduction, w: Aeneas Silvius Piccolomini, Europe (c. 1400-1458), translated by R. Brown, introduced and annotated by N. Bisaha. Washington: The Catholic University of America Press.

Buczek, K. (1935): Anzelm Polak, w: Polski słownik biograficzny, t. 1. Kraków: PAU, Ossolineum.

Buczek, K. (1963): Dzieje kartografii polskiej od XV do XVIII wieku: zarys analityczno-syntetyczny. Wrocław: PAN.

Chemperek, D. (2003): Wespazjan Kochowski - Jan Gawiński: literackie dialogi i turnieje, w: Wespazjan Kochowski w kręgu kultury literackiej, red. D. Chemperek. Lublin: Wydawnictwo UMCS.

Chemperek, D. (2005): Poezja Jana Gawińskiego i kultura literacka drugiej połowy XVII wieku. Lublin: Wydawnictwo UMCS.

Curtius, E.R. (2009): Literatura europejska i łacińskie średniowiecze. Kraków: Universitas.

Cytowska, M., Szelest, H. (1994): Literatura rzymska. Okres cesarstwa. Autorzy chrześcijańscy. Warszawa.

Estreicher, K. (1870): Bibliografia polska, t. XVII. Kraków: Wydawnictwo Uniwersytetu Jagiellońskiego.

Estreicher, K. (1963): Bibliografia literatury polskiej „Nowy Korbut", t. II. Wrocław: Ossolineum.

Gansiniec, R. (1997): Wkład czołowych przedstawicieli ziemi ślaskiej w kształtowanie się myśli poznawczej i literatury polskiego Odrodzenia, w: Pallas Silesia. Antyk na Ślasku, I, Katowice: Fundacja „Pallas Silesia”.

Gniadek, S. (1956): Traktat semantyczny Jana ze Stobnicy. „Sprawozdania Poznańskiego TPN”. 1:3-15. 
Iłowiecki, M. (1982): Dzieje nauki polskiej. Warszawa: Wydawnictwo Interpress.

Jan ze Stobnicy (1512): Introductio in Ptolemaei cosmographiam cum longitudinibus et latitudinibus regionum et civitatum celebriorum. Kraków: Florian Ungler.

Jan ze Stobnicy (1517): Introductio in Ptolemaei cosmographiam cum longitudinibus et latitudinibus regionum et civitatum celebriorum. Kraków: Hieronim Wietor.

Kaczmarek, M. (1984): Anzelm Polak, w: Literatura polska. Przewodnik encyklopedyczny, t. I. Warszawa: PWN.

Knoll, P.W. (2016): „A Pearl of Powerful Learning”. The University of Cracow in the Fifteenth Century. Leiden: Brill.

Krawiec, A. (2010): Ciekawość świata w średniowiecznej Polsce. Studium z dziejów geografii kreacyjnej. Poznań: Wydawnictwo Naukowe UAM.

Malewicz, M.H. (1980): Zjawiska przyrodnicze w relacjach dziejopisarzy polskiego średniowiecza. Wrocław: Ossolineum.

Markiewicz, H. (1996): Z dziejów plagiatu w Polsce, w: tenże, Prace wybrane, t. 2: Z historii literatury polskiej, red. S. Balbus. Kraków: Universitas.

Martines, L. (1988): Power and Imagination: City - States in Renaissance Italy. Baltimore: Johns Hopkins University Press.

Michalski, K. (1913): Jan ze Stobnicy jako przedstawiciel skotyzmu w Polsce. „Sprawozdania z Czynności i Posiedzeń AU” 18: 12-13.

Michalski, K. (1915): Michał z Bystrzykowa i Jan ze Stobnicy jako przedstawiciele skotyzmu w Polsce. „Archiwum Komisji Badania Historii Filozofii w Polsce". 1, 1: 21-80.

Niklewiczówna, K. (1998): Hiszpańsko-polskie zwiazki literackie, w: Słownik literatury staropolskiej. Wrocław: Ossolineum.

Ojrzyński, R. (2014): Obraz Polski i Polaków w pismach Eneasza Sylwiusza Piccolominiego (papieża Piusa II). Warszawa: DIG.

Palacz, R. (1970): Jan ze Stobnicy. „Materiały do Historii Filozofii Średniowiecznej w Polsce". 1, 12: 23-38.

Polski Słownik Biograficzny. (1962-1964), t. X. Wrocław: Ossolineum. 
Rio del, A. (1970): Historia literatury hiszpańskiej, t. 1, przeł. K. Piekarec. Warszawa: PWN.

Rott, D. (1995): Staropolskie chorografie. Katowice: Wydawnictwo UŚ.

Rott, D. (1997): Wawrzyniec Korwin. Wczesnorenesansowy humanista ślaski. Katowice: Wydawnictwo Uniwersytetu Śląskiego.

Sokolski, J. (2010). Natura lubi się ukrywać: Historia naturalis - magia naturalis - philosophia naturalis w Europie wczesnonowożytnej, w: Człowiek wobec natury: humanizm wobec nauk przyrodniczych, red. J. Sokolski. Warszawa: Neriton.

Skubała-Tokarska, Z. (1983): Organizacja nauki w Polsce, w: Zarys dziejów nauk przyrodniczych w Polsce. Warszawa: Wiedza Powszechna.

Staszewski, J. (1966): Historia nauki o Ziemi w zarysie. Warszawa: PWN.

Szczegóła, H. (1967): Jan z Głogowa. Katowice: Wydawnictwo Śląsk. Szelińska, W. (1980): Chorografia Regni Poloniae Jana Długosza. Kraków: Wydawnictwo Naukowe Wyższej Szkoły Pedagogicznej. Tarnowska, I. (1962-1964): Jan ze Stobnicy, w: Polski Słownik Biograficzny 10. Wrocław: Ossolineum.

Tazbir, J. (1973): Rzeczpospolita szlachecka wobec wielkich odkryć. Warszawa: Wiedza Powszechna.

Wielgus, S. (2005): Zachodnia i polska nauka średniowieczna - encyklopedycznie. Płock: Płocki Instytut Wydawniczy.

Zawadzki, R.K. (2013). Wawrzyniec Korwin - życie i twórczość renesansowego humanisty. (Studium, tekst łaciński, komentarz i przekład). Częstochowa: Wydawnictwo Akademii im. Jana Długosza.

Zawadzki, R.K. (2018). „Terrae Sanctae et urbis Hierusalem descriptio" brata Anzelma Polaka. Niektóre walory literackie utworu. „Pamiętnik Literacki” CIX, z. 4: 23-38.

Ziomek, J. (1994): Prace ostatnie. Literatura i nauka o literaturze. Warszawa: PWN. 